Brit. J. industr. Med., 1949, 6, 125.

\title{
THE CARE OF THE LEAD WORKER *
}

\author{
BY \\ RONALD E. LANE \\ From the Nuffield Department of Occupational Health, Victoria University, Manchester
}

(RECEIVED FOR PUBLICATION, FEBRUARY 22, 1949)

In establishing these lectures Dr. Milroy expressed the desire that they should " promote the advance of medical science along with the interests of ... social welfare." He pointed out that there was " a vast amount of protracted malaise and suffering, disablement or lessened capacity for industrial work, whose origination will probably be found to be largely due to the neglect of some of those natural laws of healthy existence, with the consideration of which the science of public hygiene professes to deal." I therefore make no apology for the choice of my subject, and this for two reasons ; first because the history of industrial lead poisoning in this country over the last eighty years provides an excellent example of preventive medicine, and second because-though lead poisoning is happily now a rare disease, the use of lead is still increasing, and if this is to remain safe the informed help of medical men will be required.

\section{Progress Toward Sound Standards of Safety}

In these lectures I have no intention of discussing the voluminous literature on lead poisoning. This has grown rapidly with the years and has recently been surveyed by Cantarow and Trumper (1944), nor do $I$ intend to discuss clinical plumbism, but rather in a brief review of the history of the prevention of this disease in Great Britain I hope to demonstrate our method of dealing with problems of this type, showing its weakness as well as its strength. Then I wish to discuss in the light of experience some of the practical problems involved in the care of the lead worker, in the hope that the doctor faced with this task may be better able to evaluate some of the contradictory advice he may be offered.

\section{Historical Facts and Survey of the Uses of Lead}

Lead has been used from ancient times. Its peculiar properties of malleability and resistance to corrosion, together with the chemical and physical properties of many of its compounds, have rendered it of inestimable value in many fields of human

- Being the Milroy Lectures delivered before the Royal College of Physicians in London in May 1947. activity. Its consumption has steadily risen and at the present time it is scarce throughout the world. It is perhaps not fully realized how widespread is its use ; in a survey carried out by the United States Public Health Service in 1940, involving nearly 17,000 factories and a million and a half workers, it was found that rather more than half were handling lead or its compounds. The steady increase in the consumption in this country up to 1939 suggests an expansion in its use here; despite this, the incidence of lead poisoning in Great Britain has fallen steadily throughout the century (fig. 1).

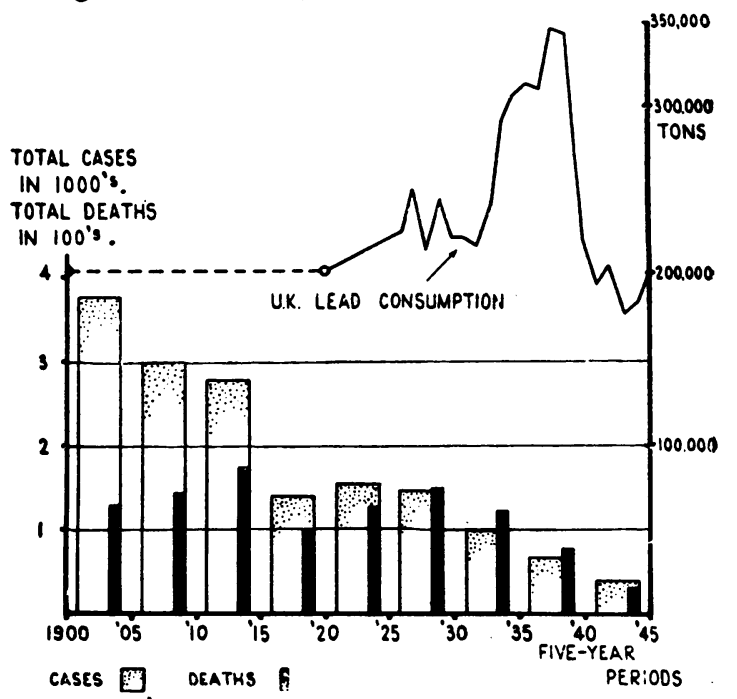

Fig. 1.-Notified cases of lead poisoning, 1900-45.

The toxic effects of lead were known to the ancients. Throughout the last 2,000 years its clinical manifestations have been recognized. At the end of the eighteenth century Percival (1774) published a small work which dealt with "Observations and Experiments on the Power of Lead," and it was over a hundred years ago that Tanquerel des Planches (1839) published his famous treatise giving a detailed and accurate account of lead poisoning, but it was not until the end of the nineteenth century that legislation was introduced to protect the lead 
worker from the hazards of his occupation. Sigerist (1943) maintains that the history of industrial disease reflects some of the most important chapters in the progress of human civilization and social evolution. This is well illustrated by the history of lead poisoning in the industry of Great Britain, which shows how our industrial society has sought to protect itself from this particular type of social ill. In the evolution of our present methods, workers, employers, legislators, and doctors have played their respective parts. In some cases these have been progressive, in others the reverse.

The efforts of early reformers like Shaftesbury and Fielden had been directed to conditions in the

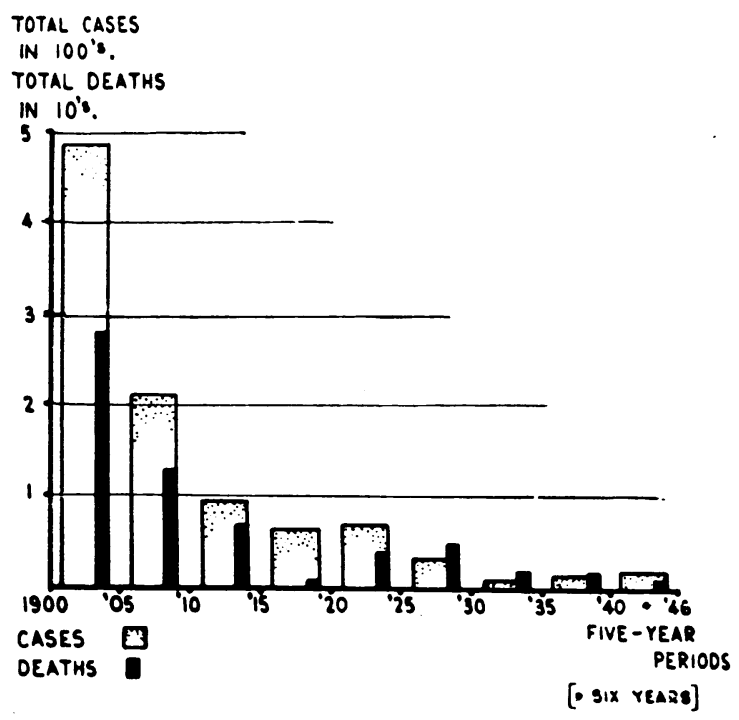

FIg. 2.-Notified cases of lead poisoning in white and red lead trades, $1900-46$.

textile mills, the abuse of juvenile labour, and long hours of work. The next period dealt with what Legge (1934) calls " the toll of life and limb resulting from unguarded machinery," and then, finally, at the end of the century the attack on toxic substances began. What those two Manchester physicians Percival and Ferrier had done for the textile industry at the beginning of the century, Legge and Oliver did for the lead trades a hundred years later. The name of Sir Thomas Legge, then His Majesty's Senior Medical Inspector of Factories, will always be associated with the cause of the lead worker. While there was probably an element of scientific curiosity about his approach to this problem, the stronger motive for his unsparing efforts was undoubtedly to be found in his genuine distress and indignation at the sight of large numbers of workers poisoned in the course of their work. The historica! side is emphasized because it is important to see this subject, not in isolation, but in relation to the whole subject of occupational disease, and as a part of a bigger picture of industrial medicine. While industrial medicine must never be confined either to toxicology or to a casualty service, it must nevertheless be realized that it was the existence of these obvious ills in our factories and workshops which gave the doctor opportunities to come into industry in the first place, and if in dealing with them he discovered new problems of even greater importance, because of their wider distribution, it is not surprising that they have remained unrecognized by many, as did the old industrial diseases of the past.

Under the Factories Act of 1895 lead poisoning became a notifiable disease; this was an important landmark because from this time on its incidence was to become widely known. Reports of departmental committees set up over the next few years to consider its incidence in such industries as pottery and coach painting provide interesting side-lights on those industries at that time. Often the claims and suggestions of the workers were, in the light of modern knowledge, correct, but these were frequently met by resistance on the part of small groups of employers. Gradually, however, these objections were overcome, and as the years have passed it has become common practice to introduce regulations and orders where it was shown that a trade or process was dangerous. In drawing up these codes it is always the custom to consult workers and employers in the industry, and to work out with them the best methods for providing safe working conditions. There are at present eleven such codes (nine requiring medical examination) dealing with lead.

White Lead (fig. 2).-An excellent example is provided by the early history of the white lead industry. In the latter part of the nineteenth century the manufacture of lead carbonate was a prolific cause of lead poisoning. Charles Dickens in "All the Year Round" drew attention to it, and in 1882 the Guardians of the Poor of Holborn complained of the cases of lead poisoning which were becoming a charge upon them. There were apparently in the wards of the Union Workhouse at this time no less than fifty-four cases (six were men and forty-eight women). The women were all engaged in the manufacture of white lead. A white lead works in London produced sixty-four cases of lead poisoning in nine months. These were the conditions when the first legislation dealing with this industry was introduced in 1883, and it was not until fifteen years later that regulations prohibiting 


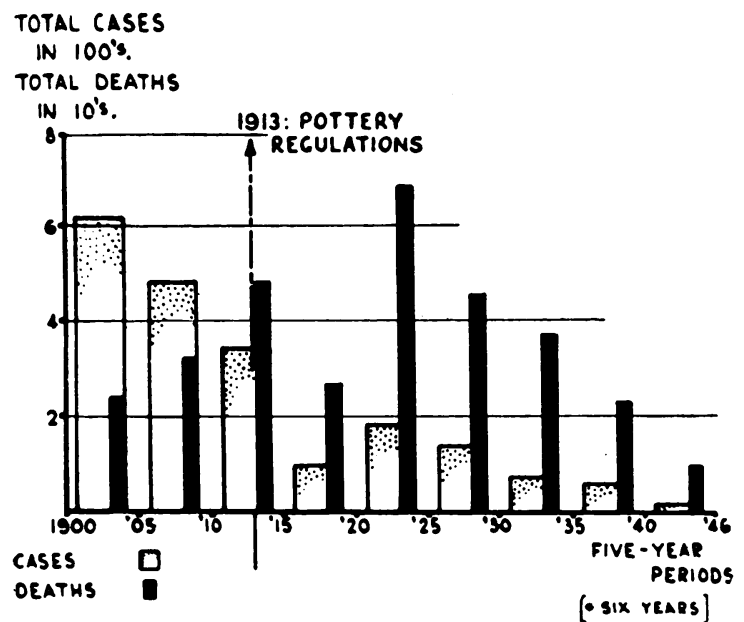

Fig. 3.-Notified cases of lead poisoning in pottery industry, $1900-46$.
TOTAL CASES

IN 1OO's.

TOTAL DEATHS

IN $10^{\circ} \%$

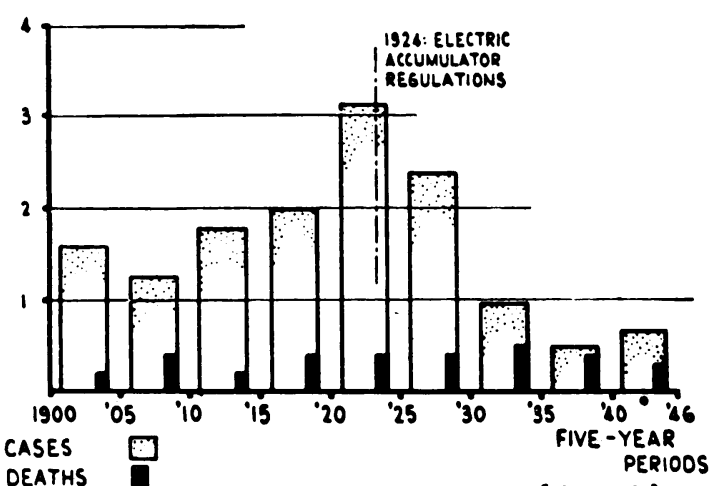

[ogix YEARS]

Fig. 4.-Notified cases of lead poisoning in electric accumulator industry, 1900-46.
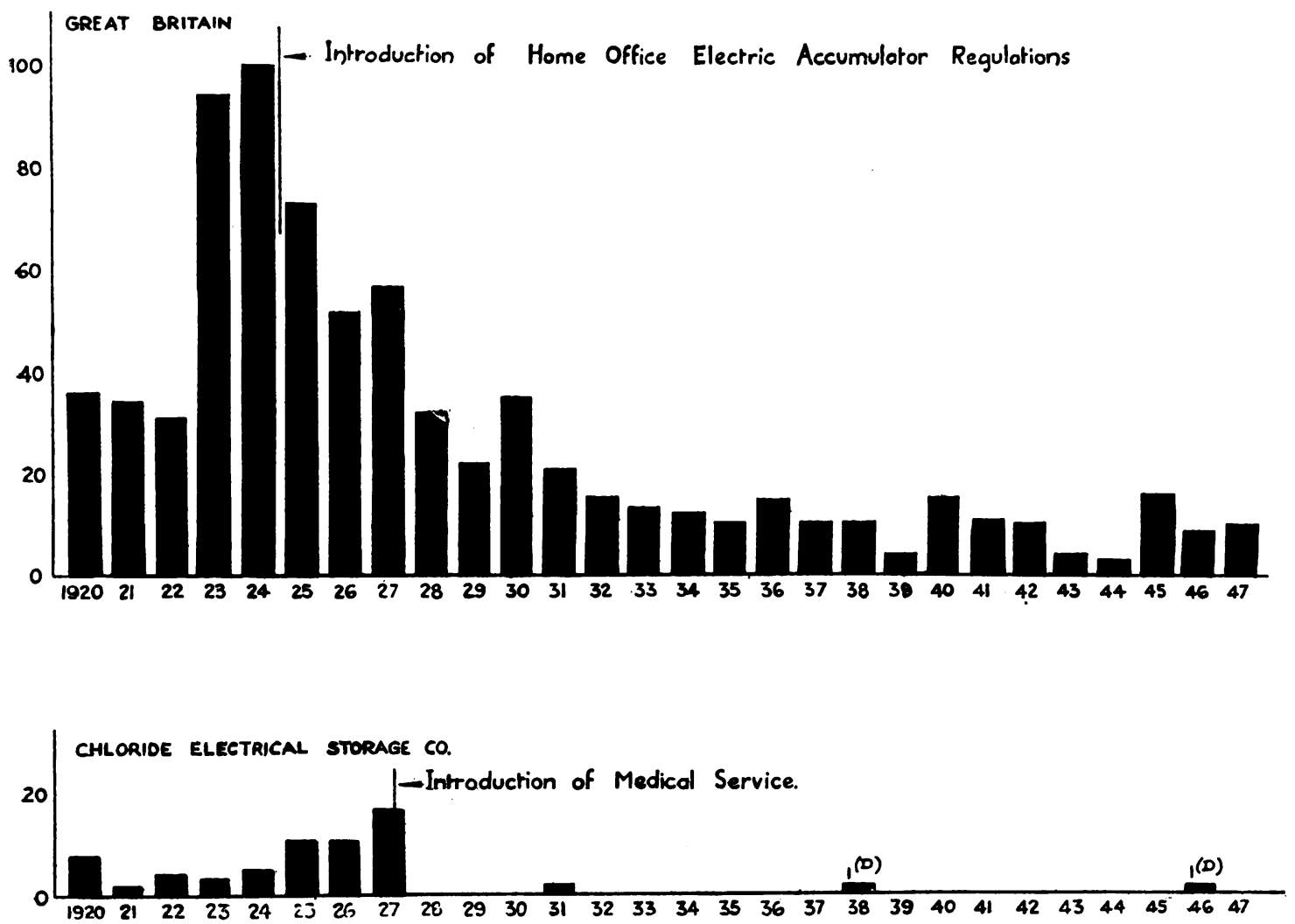

Fig. 5.-Lead poisoning in electric accumulator works. 
the employment of women in certain of the more dangerous processes were introduced. There was still such " sanctity of property," and " freedom of enterprise" was given such scope that efforts to improve the lot of the factory worker, even when his work involved him in considerable danger, were met by stubborn opposition.

The Pottery Industry (fig. 3).-A small geographical area of North Staffordshire is aimost completely devoted to the manufacture of pottery. There are some 350 different works and some 70,000 workers. At the end of the nineteenth century the incidence of lead poisoning had reached alarming proportions and the pottery industry was declared a dangerous trade, and in 1894 special rules covering it were introduced. By these an employer was required to provide overalls, washing accommodation, cleaning equipment, and eating in the factory was forbidden. Other similar codes of rules were introduced from time to time, but with limited success, until 1913, when the Pottery Regulations took effect. These regulations tackled the problem in two ways. They laid down certain minimum standards for general working conditions and they prescribed the detailed regulation of various processes in which lead risks were encountered. It is probable that these regulations were the most successful that have ever been introduced, though it is difficult to judge because of the increased use about this time of leadless or low-solubility glaze. There is no doubt, however, as to the results. In 1898 there were 457 cases in the year, in 1919 this number had fallen to twenty-one, and the year before the war there were seven cases reported.

Frequently we find that the progressive employer had forestalled the introduction of regulations and had voluntarily established improved conditions, so that the function of legislation was merely to impose on the whole trade those standards and conditions which the more progressive members had shown to be desirable. An example is seen in the electric accumulator industry (fig. 4).

The Electric Accumulator Industry.-The history of the electric accumulator industry is interesting. It was working under a code of rules which were introduced in 1903. In the years immediately following the 1914-18 war the incidence of lead poisoning in this comparatively small industry rose alarmingly, and in 1925 regulations were introduced. These were based on the practices already employed by the most progressive of the battery manufacturers. In other words the most advanced practice was made to apply to the whole industry. This resulted in a drop in the number of cases of poisoning in the industry, but despite these regulations cases in the particular company which served as a model continued to rise as the company grew in size. It was not until three years later, when a medical service was introduced into this particular factory, that cases disappeared : a further voluntary step forward had been taken by the employer (fig. 5).

The Incidence of Lead Poisoning by trade does not correspond to the weight of lead used, but depends upon the form in which it is used. The approximate distribution of our annual lead consumption by trades is shown in fig. 6 . It will be seen immediately that the bulk of lead is used in cable manufacture and in sheet and pipe work. There is, however, practically no lead poisoning in these industries,

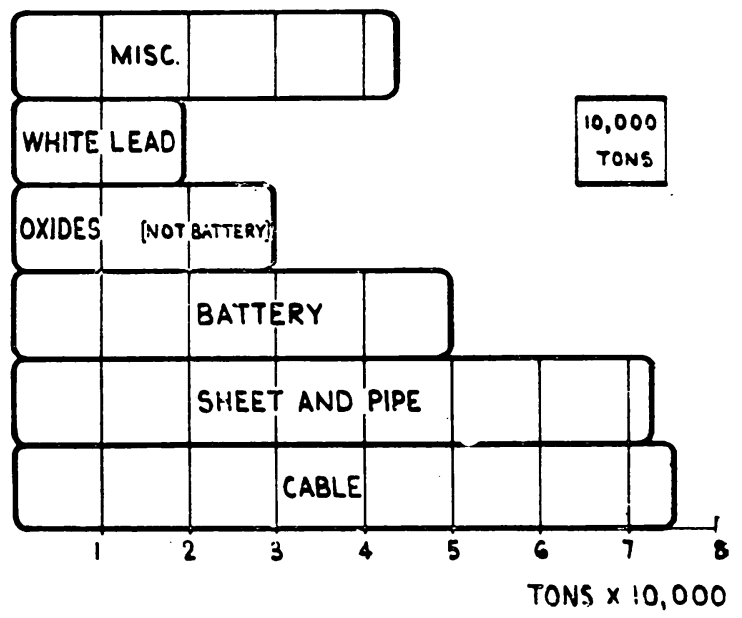

Fig. 6.-Main use of lead in 1945.

where the lead is used in metallic form. The dangerous industries are those in which lead is encountered in dusty form.

New Hazards for Old.-As the years have passed the use of lead in certain industries has dwindled, while new uses in other industries have been found. For instance the use of lead in coach painting has. been largely superseded by modern methods, but a new hazard has been added in the manufacture of motor car bodies. In this process a leadcontaining alloy is used in considerable quantities in completing the body work. Excess of lead is removed by a rapidly revolving abrasive disc, with the result that fine particles of lead are thrown into the atmosphere. When this process first started in America a large number of cases of lead poisoning resulted, and when it was introduced into this country before the war difficulties were encountered. At present some $28 \mathrm{lb}$. of 80 per cent. alloy is used for a car body. In the United States they have, by better engineering, been able to reduce the quantity 
to approximately $6 \mathrm{lb}$. While this shows an improvement, this process is likely to remain dangerous so long as open discing is employed. It was interesting recently to see, on one of America's busiest car production lines, hand filing replacing discing on this process, with excellent results from the point of view of hygiene.

Another use of lead has been found in producing anti-knock petrol. This involved the manufacture of lead tetra-ethyl, which is a highly toxic substance. The manufacturers realized the dangers and evolved elaborate methods of protection for those engaged on the process. The fact that it has been possible to manufacture and mix this highly toxic substance, and distribute it throughout the world with comparative safety, is due in part to the work of Kehoe and his associates (1935), and provides an excellent illustration of the type of medical investigation that is necessary, and the planning and administration that are subsequently required, if processes of this type are to be carried on without danger to those employed.

The recent extensive use of lead as an insecticide has, in the U.S.A., introduced new health problems and is throwing an added strain on already restricted supplies. These are but a few of the new uses that are being found for it ; as it is superseded in one industry as a result of technical advances, progress in other fields demands its introduction.

\section{Portals of Entry}

It early became obvious that if progress were to be made in the control of industrial lead poisoning certain factual knowledge was essential.

The Respiratory Tract.-Since the seventeenth century the respiratory tract had been suspected to be the main portal of entry, but this appears to have been largely ignored in the earliest legislation, which, beyond providing for washing, did very little else. It was not surprising, therefore, that these first regulations met with little success. Goadby reported to the Departmental Committee on the use of lead in the pottery industry (1910) that the respiratory tract was - the main portal of entry, and Legge continually preached this and based upon it the regulations covering the lead industries in this country.

The Gastro-intestinal Tract.-Considerable quantities of lead enter the gastro-intestinal tract, but pass through the gut without absorption. It is probable that much of the lead dust that is inhaled is eventually swallowed and appears in the fæces; in fact the estimation of fæcal lead may be used as an indication of the hazard to which a man is subjected, though it does not give any indication of the quantity of lead absorbed. Although lead is not so readily absorbed from the gastro-intestinal tract as from the respiratory tract, absorption by this route does take place and appropriate care is necessary to prevent it, so that eating, chewing, and smoking are prohibited in a lead works under regulations.

The Skin.-Certain organic lead compounds can enter the circulation through the skin. Lead tetraethyl is the only one of these likely to be encountered in industry, and its handling in the unmixed state is very carefully controlled. When blended with petrol it is diluted to the extent of some one part in 1,200 , and in this form presents no special danger. Recent experience (H.M. Inspector of Factories Report, 1944) would emphasize the danger of cleaning out storage tanks in which ethyl petrol had been stored, unless special precautions are taken. Here absorption is mostly by way of the respiratory tract.

Danger of Dust and Fumes.-Consideration of these facts makes it obvious that it will be in those trades which expose the worker to lead dust or lead fume that poisoning is likely to be found. Cold metallic lead is harmless, but when it is melted fume is given off, though not in appreciable quantities until the temperature reaches $800^{\circ} \mathrm{C}$. In addition, oxides form on the surface of melted lead and their removal is likely to give rise to a respirable dust unless great care is exercised. Lead fumes may also be produced in lead burning (welding), in shipbreaking where heavily painted steel plates are cut through with the acetylene torch, and in homogeneous welding and numerous other processes. All these occupations which expose the worker to lead fumes are potentially dangerous and will need special control. Most trouble, however, comes from the dusty trades where lead compounds are encountered or where metallic lead is present in such a fine state of sub-division that it can be breathed.

\section{Lead in Air Estimation}

It early became obvious that some objective measure of a hazard was necessary. Engineers and chemists who were working to improve conditions demanded some specification to which to work. As early as 1909 Legge, with the chemical assistance of Duckering, had set a limit of $5 \mathrm{mg}$. per $10 \mathrm{cu}$. $\mathrm{m}$. in the air breathed. He pointed out that if contamination were kept below this, cases of serious lead poisoning would rarely occur. By modern standards this figure is far too high but its introduction by Legge shows a definite advance in the 
TABLE 1

SHOWING RESULT OF IMPROVING WORKING CONDITIONS

\begin{tabular}{|c|c|c|c|c|}
\hline \multirow[b]{2}{*}{ No. } & \multicolumn{2}{|c|}{ December 1927} & \multicolumn{2}{|c|}{ December 1929} \\
\hline & $\begin{array}{l}\text { Punctate } \\
\text { basophils } \\
\text { (per million } \\
\text { R.B.C. }\end{array}$ & $\begin{array}{c}\text { Lead in } \\
\text { air, } 11 \\
\text { det. (mg. } \\
\text { per } 10 \\
\text { cu. } m .)\end{array}$ & $\begin{array}{c}\text { Punctate } \\
\text { basophils } \\
\text { (per million } \\
\text { R.B.C.) }\end{array}$ & $\begin{array}{l}\text { Lead in } \\
\text { air, } 12 \\
\text { det. ( } \mathrm{mg} \text {. } \\
\text { per } 10 \\
\text { cu. } \mathrm{m} .)\end{array}$ \\
\hline $\begin{array}{c}1^{1} \\
2 \\
3 \\
4 \\
5^{2} \\
6 \\
7 \\
8^{1} \\
9 \\
10^{2} \\
11^{1} \\
12 \\
13 \\
14 \\
15 \\
16 \\
17 \\
18 \\
192 \\
20 \\
21 \\
22 \\
23 \\
24 \\
25 \\
26 \\
27 \\
28 \\
29\end{array}$ & $\begin{array}{l}\text { 13,200 S.M.L. } \\
\text { 6,100 S.M.L. } \\
\text { 1,500 S.M. } \\
\text { 5,700 S.M.L. } \\
\text { 27,100 S.M.L. } \\
\text { 12,100 S.M. } \\
\text { 4,500 S.M.L. } \\
\text { 11,000 S.M.L. } \\
\text { 4,000 S.M. } \\
\text { 32,300 S.M.L. } \\
\text { 10,500 S.M.L. } \\
\text { 4,300 S.M. } \\
\text { 6,100 S.M. } \\
\text { 6,600 S.M.L. } \\
\text { 5,500 S.M.L. } \\
\text { 7,100 S.M. } \\
\text { 5,000 S.M.L. } \\
\text { 6,100 S.M.L. } \\
\text { 44,800 S.M.L. } \\
\text { 3,100 S.M.L. }\end{array}$ & $\begin{array}{l}5 \cdot 4 \\
4 \cdot 7 \\
4 \cdot 2 \\
3 \cdot 5 \\
4 \cdot 4 \\
4 \cdot 3 \\
8 \cdot 8 \\
5 \cdot 3 \\
7 \cdot 1 \\
3 \cdot 6 \\
7 \cdot 7\end{array}$ & $\begin{array}{c}800 \mathrm{~S} . \\
2,100 \mathrm{~S} . \\
6,000 \mathrm{~S} . \\
1,400 \mathrm{~S} . \mathrm{M} . \\
2,400 \mathrm{~S} . \\
1,500 \mathrm{~S} . \\
\text { 3,800 S. } \\
2,300 \mathrm{~S} . \\
600 \mathrm{~S} . \\
1,600 \mathrm{~S} . \\
2,400 \mathrm{~S} . \\
3,500 \mathrm{~S} . \mathrm{M} . \\
2,100 \mathrm{~S} . \\
500 \mathrm{~S} . \\
\text { Free }\end{array}$ & $\begin{array}{l}1.9 \\
2.4 \\
2.8 \\
1.6 \\
1.9 \\
2.0 \\
2.5 \\
1.4 \\
2.8 \\
1.2 \\
1.7 \\
1.1\end{array}$ \\
\hline Av. & 10,800 S.M.L. & $5 \cdot 4$ & $2,100 \mathrm{~S}$ & 1.9 \\
\hline
\end{tabular}

approach to the problem; it is the first effort to set a definite limit to air contamination.

This figure remained unchallenged for some 25 years, when Russell and others (1933) set a new safety limit of $1.5 \mathrm{mg}$. per $10 \mathrm{cu}$. m. Working independently in this country I suggested in 1936 that the maximum permitted contamination of the atmosphere with lead be fixed at $2 \mathrm{mg}$. per $10 \mathrm{cu}$. $\mathrm{m}$. (Lane, 1936). The suggestion made by Hamlin and Weber (1947) that a return should be made to the old limit of $5 \mathrm{mg}$. per $10 \mathrm{cu}$. $\mathrm{m}$. in the brass foundry industry is untenable, since they admit six cases of poisoning a year under such conditions. In Table 1 are recorded the results of exposure of this magnitude to lead oxide. Drinker (1947) has recently drawn attention to the need for less stringent standards where the more insoluble lead compounds are concerned.
This method of hygienic control has much to be said for it and should be in use wherever there is an appreciable lead hazard. Air sampling may be carried out by one of three methods ; the filter, the impinger, or the electrostatic precipitator. Chemical methods of estimation of lead must be selected to suit the particular conditions of the industry, taking into consideration such questions as " interfering substances" and the expected lead contamination of the atmosphere. It is well to have regular routine surveys of this type carried out, and for this purpose fixed sampling spots should be used.

This method is not by any means infallible, it is frequently found that while "lead in air" figures have been satisfactory, evidence of excessive absorption has still been present. This is particularly likely to happen if the worker is engaged on a process where lead in the form of paste or sludge is allowed to dry on the clothing. This is apt to give rise to what might be termed a "personal dust"imperceptible, but sufficiently real to produce a rise in the lead content of the air the worker actually breathes, though not materially affecting the general atmosphere tested.

\section{Need for Biological Tests of Exposure}

While, therefore, "lead in air" determinations have an important place in the control of lead processes, it must be stressed that they provide but an indication. The final test must be the biological one : what is actually happening to the man must be known. This depends on dosage, which, in turn, is determined not only by the concentration of lead in the air, but on two other factors ; (1) time, and (2) dust retention.

Length of Time of Exposure.-The length of time a worker is exposed will largely determine his daily dosage. Hours of work are therefore of the greatest importance, and when atmospheric contamination approaches the maximum limit these hours should be just as strictly controlled as the lead in air ; otherwise tissue concentration will rise to undesirable levels. It is wise, therefore, to insist on a forty-hour week maximum for all heavily exposed workers $(1.5 \mathrm{mg}$. per $10 \mathrm{cu}$. m.), whilst in certain processes where control is of necessity less certain only a thirty-six-hour week in contact may be permitted with safety, or perhaps alternative employment by four-weekly periods may be insisted upon. It is surprising that more attention has not been paid to hours of work in the Codes of Regulations.

Dust Retention.-The other controllable factor which will influence dosage in addition to the lead in air concentration and length of exposure is depth 
of respiration, influenced for example by the physical effort involved in the work. Hepple (1930) found that with low concentrations such as are found in industry, for shallow breathing, while at rest, some 16 per cent. of the lead which enters is retained, and that on deeper breathing, such as results from gentle exercise, 33 per cent. is retained. In other words, with deeper breathing not only is more lead introduced into the respiratory tract, but twice as much is retained.

Delayed Symptoms. - By careful attention to these details it has apparently been possible to keep large numbers of men quite fit. It has certainly been possible to keep them free from symptoms, but in view of the insidious nature of the action of lead it is of the greatest importance that we should be certain not only that it is producing no toxic episodes, but that it is producing no slow or long-term changes which may shorten life or affect health after middle age. Such a change is more difficult to detect. There is one particular action about which we must be certain : the cardiovascular and renal effects. There has been a tendency in the U.S.A. to think lightly of our reports in this country of " chronic nephritis" as a late effect of lead poisoning (Mayers, 1947). Perhaps the peculiar conditions of much American industry and the greater tendency of workers to move from job to job, makes long term exposure less common there, or renders changes more difficult to detect. There is no doubt that the " tight communities" of Great Britain, particularly as they existed forty years ago, gave much better opportunity for observation of these long-term effects. This problem is of great practical importance.

\section{The Kidneys and Hypertension}

The effect of lead upon the kidneys has been widely discussed and has been the subject of considerable controversy. Animal experiments have been carried out on rabbits, guinea-pigs, and cats, and various techniques have been employed. The majority of the investigators report changes of two types, tubular and vascular. Further consideration of these results leads to the view that the tubular changes have resulted from very heavy exposure of an acute type, and the work of Bell and others (1925) on human cases of cancer injected with colloidal lead preparations would confirm this. Under these conditions these workers found marked degenerative changes in the renal tubules. It must be stated at once that this represents the reaction to gross assault by a heavy metal, and is not comparable with conditions involving long-continued exposure to smaller doses; it will not therefore be considered any further.
The vascular lesions reported in animals have been observed by most workers in this field, the most common finding being a thickening of the intima in the smaller renal vessels, and most workers are of opinion that the changes seen in animals are of the type which would proceed to a terminal nephro-sclerosis.

In this country chronic renal changes have been accepted as a sequela of industrial lead poisoning and have ranked for compensation accordingly. The evidence on which this is based was largely clinical, but it was of such weight as to demand attention. Oliver (1914) says, "Of all the internal organs the kidneys are perhaps those in which structural changes are most marked. Because interstitial nephritis or contracted kidney is the most common pathological event in chronic plumbism it has come to be regarded as the typical renal lesion of lead poisoning. It is undoubtedly the lesion of chronic lead poisoning ; it is found in persons who have worked in lead for years." Legge and Goadby (1912) discuss the Registrar General's figures for 1900-02, which show a rate from "Bright's Disease" among lead workers of 160 as compared with thirty-five for all males. They regard this as confirmatory evidence " if any were needed " that chronic Bright's Disease is a sequela of lead poisoning.

The lag of some twenty-five years between the fall in the number of deaths from lead poisoning and the introduction of legislation controlling working conditions is clearly seen in fig. 3 , and would appear to be evidence in favour of the contention of the older workers.

Many other observers describe vascular changes in the kidneys of lead workers, and Fishberg (1939) states that the renal lesions are arteriosclerotic, though he qualifies this by saying that in a small number of cases there is an arteriolar necrosis similar to that found in malignant hypertension. The work of Nye (1933) in Queensland is important. He records that, of thirty-four individuals who suffered from serious lead poisoning with palsies during their childhood, twenty-four developed renal disease later in life. His observations would suggest that young tissue is particularly susceptible to lead. Most American workers regard the evidence of kidney damage in chronic lead poisoning as far from convincing.

Over the last fifteen years I have seen nine deaths from hypertension, with renal failure, in lead workers who had been exposed in the "bad days" of the industry to very severe lead absorption, estimated at more than $5 \mathrm{mg}$. per $10 \mathrm{cu}$. m. (Table 2). These men all showed a similar clinical picture. They had worked steadily for periods varying from 
TABLE 2

ANALYSIS OF NINE DEATHS FROM HYPERTENSION WITH RENAL FAILURE IN LEAD WORKERS

\begin{tabular}{|c|c|c|c|c|c|}
\hline \multirow[b]{2}{*}{ Case } & \multirow{2}{*}{$\begin{array}{c}\text { Age } \\
\text { at } \\
\text { death }\end{array}$} & \multirow{2}{*}{$\begin{array}{c}\text { Years } \\
\text { exposure }\end{array}$} & \multirow[b]{2}{*}{ Process } & \multicolumn{2}{|c|}{ Family history } \\
\hline & & & & $\begin{array}{l}\text { Father } \\
\text { died }\end{array}$ & $\begin{array}{c}\text { Mother } \\
\text { died }\end{array}$ \\
\hline $\begin{array}{l}1 \\
2 \\
3 \\
4 \\
5\end{array}$ & $\begin{array}{l}46 \\
49 \\
52 \\
50 \\
51\end{array}$ & $\begin{array}{l}22 \\
32 \\
24 \\
18 \\
20\end{array}$ & $\begin{array}{l}\text { Hand } \\
\text { paster }\end{array}$ & $\begin{array}{c}78 \\
76 \\
? \\
82 \\
72\end{array}$ & $\begin{array}{l}82 \\
84(\mathrm{~A}) \\
60 \\
81 \\
69\end{array}$ \\
\hline 6 & 51 & $\begin{array}{l}\text { (started } \\
\text { at 17) }\end{array}$ & $\begin{array}{c}\text { Heavy } \\
\text { dust }\end{array}$ & 70 & 75 \\
\hline 7 & 49 & $\begin{array}{c}30 \\
28 \\
\end{array}$ & $\begin{array}{l}\text { and } \\
\text { fume ex }\end{array}$ & $\begin{array}{l}80 \\
49\end{array}$ & $\begin{array}{r}78 \\
63\end{array}$ \\
\hline 8 & 42 & $\begin{array}{l}\text { (started } \\
\text { at 14) }\end{array}$ & posure & $\begin{array}{l}\text { (lead } \\
\text { p.) }\end{array}$ & $\begin{array}{l}\text { (heart } \\
\text { dis.) }\end{array}$ \\
\hline 9 & 46 & 21 & $\begin{array}{l}\text { Hand } \\
\text { paster }\end{array}$ & \multicolumn{2}{|c|}{ No records } \\
\hline
\end{tabular}

within one month to a year of their death due to renal failure. In only one case was it possible to find any typical family history suggesting hypertension, and in this instance the patient's father had also died from "lead poisoning" at the age of 49. The striking feature of these deaths is the age at which they occurred : an average of 48.4 ranging between 42 and 52 . It has been impossible to determine the actual number at risk, but it is estimated that these deaths occurred in a group of about 150 men who remained at high risk sufficiently long to come under review. While it is fully realized that this experience has little statistical significance, it is considered worthy of record that there should be a high incidence of this type of clinical case in a comparatively small group of workers.

I am indebted to Dr. Davson for the following histological report.

Examination of the kidneys at necropsy showed no uniform picture. It would appear that the microscopical appearances depended upon the chronicity of the process. In the more slowly developing cases there was a diminution in the number of glomeruli, some of which were completely fibrosed, others showing peri-glomerular fibrosis, while the vessels showed widespread hyaline arterio-sclerosis of the afferent arteriols and intralobular arteries. Larger arteries showed intimal fibrosis. The picture in these cases was indistinguishable from benign hypertension with progressive renal damage. On the other hand some of the more rapidly progressive cases showed a picture very similar to the malignant phase of arteriolar necrosis. In two other cases certain of the glomeruli show an increase in intercapillary hyaline, somewhat resembling that seen in type 2 nephritis. These were the only cases in which the possibility of lead acting directly to produce a glomerular lesion could be postulated, but as some cases of hypertension may also show similar glomerular changes, no definite inference is justifiable.

The age at which death has occurred would suggest that the hypertension was either malignant or secondary in type (Platt, 1948) while the uneven histological changes would point to the condition being secondary. This interpretation would fit in with the findings already referred to in animal experiments in which sclerosis of the smaller renal vessels was observed following prolonged dosage with lead.

It must be stressed that this disproportionate number of deaths occurred in a small group of men who had long been exposed to bad working conditions-probably comparable with those described by the early observers. The problem that confronts us is whether similar changes are likely to be found after the mild degrees of industrial lead exposure of the present day, and it seems that a study of blood pressure and urine in a suitably exposed group will enable an answer to be given.

It was generally believed by the older workers that long-continued exposure leads to hypertension, and that this condition was unusually common in lead workers (Oliver, 1914 ; Legge and Goadby, 1912 ; Teleky, 1937 ; Fishberg, 1939). Some recent American workers are equally certain that there is no such change. Belknap (1936) for instance, concluded that there was no significant difference in the blood pressure of lead and nonlead workers of similar age groups. His findings, however, cannot be accepted as conclusive, since his sample is by no means representative, as exposure did not persist over a sufficiently long period (in only 17 per cent. did it reach between ten and twenty years). Dreesen and others (1941), in their survey of battery workers for the U.S.A. Public Health Service, were unable to discover any significant change in the blood pressure in these workers. Again, however, the same criticism must be levelled, that the majority of these workers had not been exposed to high concentrations of lead for a sufficiently long time.

Opportunity has occurred to observe over a period of twenty years a large number of lead workers, and a group of fifty-six electric accumulator pasters was selected as being particularly suitable, since their work has always been regarded as a hazardous operation and even now, in a model plant, remains one of the major lead risks. In the early period of their employment they were heavily exposed as judged by modern standards. (Lead in air from 2 to $2.5 \mathrm{mg}$. per $10 \mathrm{cu}$. m. ; punctate basophil counts 4 to 5 thousand per million; 
average lead in urine $\mathbf{2 0 0}$ gamma.) The latter half of their exposure has been at a lower level than this, but has still been considerable (lead in air 1.5; punctate basophil 2,500; average lead in urine 150 gamma). These 56 men fall in the 45 to 54

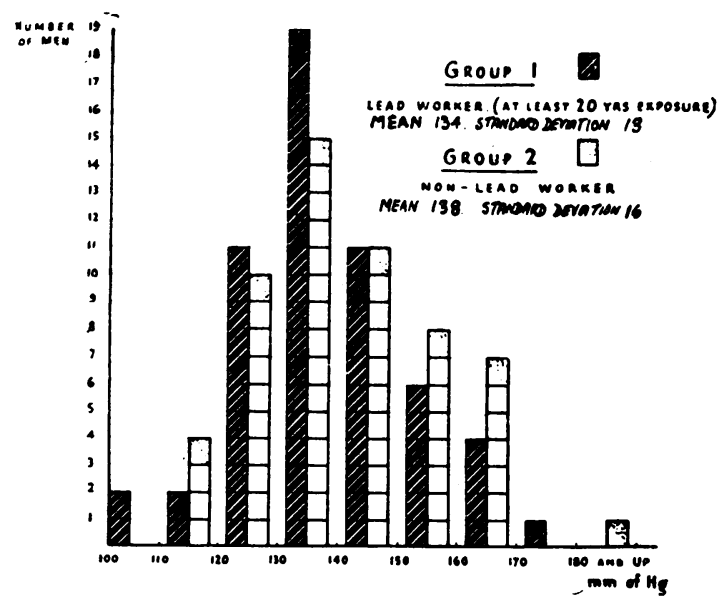

FIG. 7.-Systolic pressures in two groups of fifty-six men from the same locality and social grade, aged 45 to 55 years : lead workers and controls.

years age group. Their mean systolic blood pressure was 134 (standard deviation 13) and the mean diastolic pressure was 88 (standard deviation 10). For comparison a similar number of men of the same age group, from the same district, working in the same factory for the same period, but not in any way connected with lead, was examined. The results were as follows : mean systolic pressure 138 (standard deviation 16), mean diastolic pressure 88 (standard deviation 8) (figs. 7 and 8). As compared with standard pressures for this age group (quoted by Fishberg, 1939, after Symonds) these systolic pressures are slightly higher, as are the diastolic pressures, but this cannot be regarded as due to lead, since the difference is similar for both lead workers and non-lead workers :

$$
\begin{array}{cc}
\multicolumn{2}{c}{\text { Symonds (1923) }} \\
45-49 & 128 \cdot 2 / 84 \cdot 7 \\
50-54 & 130 \cdot 2 / 85.9
\end{array}
$$

Comparison with Maclaren's figures (1927) shows complete normality :

$\begin{array}{lcr}45 & \text { Maclaren (1927) } \\ 55 & 134-136 & 85 \\ 50 & 136-138 & 86 \\ 55 & 138-140 & 87\end{array}$

Dreesen and others (1941) report albuminuria as being twice as common in lead workers showing signs of intoxication as in non-lead workers, and they found albuminuria in 39 per cent. of workers who had been heavily exposed (3.0 mg. per $10 \mathrm{cu}$. m.) for periods in excess of fifteen years.

In my series of 56 pasters a trace of albumin was found in three cases only, while similar findings were present in two of the controls.

The fact that this group of fifty-six lead workers with over twenty years' exposure shows no significant difference either in blood pressure or in urine findings from the control group is highly significant, and can only be due to the fact that their exposure and dosage has not reached a dangerous level. This would account for the disappearance of these so-called cases of chronic Bright's Disease under the improved conditions of modern industry.

It is an important finding, because it does indicate that the standards laid down-chemical and biological-are sound, and that by the use of intelligent medical supervision we know how to eliminate lead poisoning. We can at least write the prescription ; the dispensing of that prescription is in the hands of the engineer, the other important member of the industrial health team.

It is thought wise to deal at some length with this question of standards of safety. The slow evolution of safe working conditions in the lead trades of this country has been the result of continued efforts by the Factory Department, a more enlightened attitude on the part of management, Trade Union pressure,

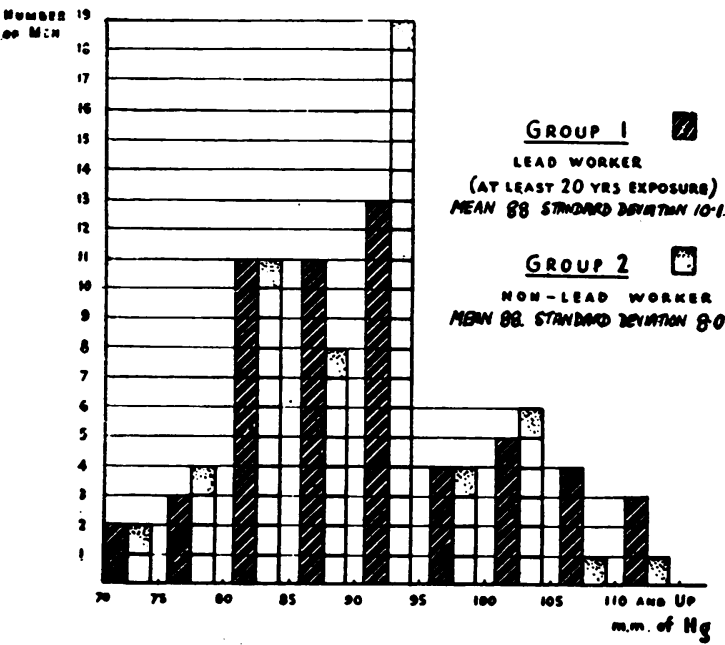

Fig. 8.-Diastolic pressure (mean $88 \mathrm{~mm}$. $\mathrm{Hg}$ ) in two groups of 56 men (lead workers and controls) from the same locality and social grade (aged 45 to 55 years).

a little scientific investigation, and a lot of action on purely empirical grounds. There has been a change in outlook among the progressive lead trades : they are no longer concerned merely to prevent obvious lead poisoning, but to ensure that there is no damage 
to health and no impairment of efficiency on the part of the worker. To ensure this, they have voluntarily adopted certain standards; these standards are safe standards, and their enforcement throughout all the lead trades seems justifiable.

\section{The Doctor and the Patient}

In nine lead trades in this country medical supervision is required by law. This provides for frequent (usually monthly) inspection by the doctor. This frequency is itself important, for doctor and patient are brought together in short, but face-to-face, interviews, which provide a good opportunity not only for the doctor to observe slight changes in the workman, but for the establishment of confidence between them which will make the task of supervision easier and more effective. A good relationship of this type is of the utmost importance : everything possible should be done to foster it. Even so, too much reliance must not be placed on the disclosure of subjective symptoms, for many a workman will decide to conceal a symptom that is troubling him because he fears that its disclosure will lead to his removal from his present job, entailing perhaps a drop in wages and separation from his friends and working group. For this reason the doctor will pay particular attention to early objective changes.

The medical supervision may be considered under the heads of selection, supervision and treatment.

\section{Selection}

Sex.-Women are excluded by law from work involving the more serious lead risks, and since some doubt has recently been expressed by Baetjer (1946) as to the need for this precaution, it is proposed to discuss it. Regulations prohibiting the employment of women in dangerous lead operations have been introduced at times in the face of opposition from groups of employers and from the women themselves, but on evidence which is considered irrefutable. Oliver (1914) states categorically that " women are more readily affected by lead than men." While one must be influenced by the observations of a shrewd clinician, it must be. stated at once that the evidence he brings to support his statement is not convincing. He himself states clearly that women have worked in greater numbers in the more dangerous processes in the white lead industry, and it was on this industry that he was largely basing his opinion. Legge and Goadby (1912) were less dogmatic. They pointed out the difficulty imposed by the inability to secure proper comparison because of different exposure, and Hamilton (1925) has expressed similar doubts. There are, however, interesting statistics to be found in the
Report of a Departmental Committee appointed to inquire into the dangers attendant on the use of lead in the manufacture of earthenware and china (1910); these make it possible to compare the incidence of lead poisoning in men and women engaged on the same work-ware cleaners, dippers and dipping assistants (fig. 9). The female incidence rate was shown to be from two to three times that of the male. It must be admitted that even these statistics do not prove the point conclusively, since it may well be held that the labour turnover among the women was higher than among the men, and that in consequence the males on risk represented a "salted" population. It is also possible that the

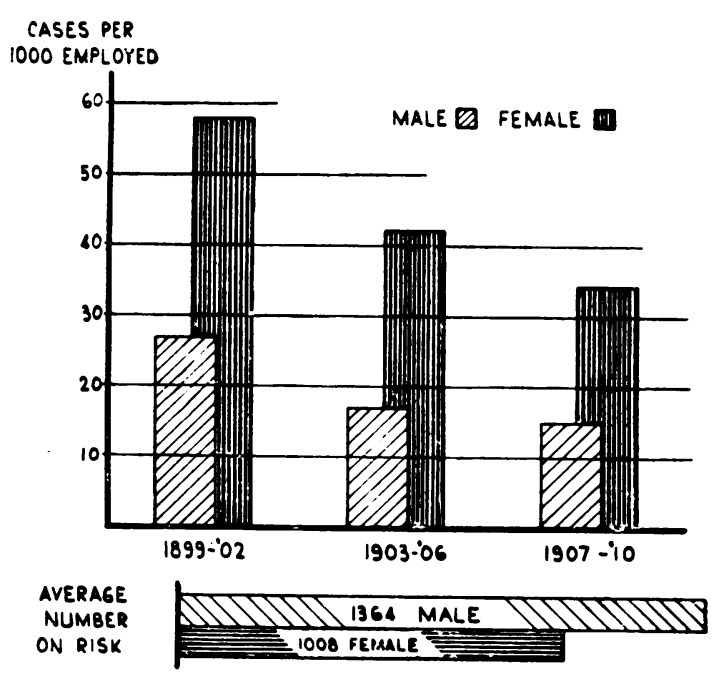

Fig. 9.-Pottery ware cleaners, dippers, and assistant dippers ; attack rate per annum, by sex.

actual operations performed by men and women, although done side by side, were more dangerous in the case of women than of men. Be this as it may, the Committee who had all these facts before it accepted this evidence as showing greater susceptibility of women to lead poisoning. This Committee was also impressed by the higher incidence of miscarriage among women engaged in lead work. In some 4,000 cases, including 191 female lead workers, the incidence of miscarriage per hundred mothers was almost three times as great among the lead workers who had worked on lead processes prior to their marriage, and almost four times as great among those who continued on lead work after marriage. This abortifacient action of lead is of course widely recognized and the evidence is unassailable; ' it must be taken into account in deciding whether or not women are to be allowed to do work involving lead exposure. 
Bell and others (1925) place the minimum toxic dose of colloidal lead at $40 \mathrm{mg}$. in females and 100 mg. in males. While some allowance must be made for weight, this alone cannot account for the difference.

There is one aspect of this problem which is often overlooked. Although women are employed on the lighter types of work, this is not always so, and they are often engaged side by side with men on work which involves, for them, a greater physical effort. This leads inevitably to a raised respiratory exchange with a greater depth of breathing. This has been shown to result in a greater retention of lead dust (Hepple, 1930), so that in addition to any greater susceptibility the actual dosage of lead per pound of body weight is likely to be raised. This may be an additional factor in producing their greater liability to lead poisoning in industry. One therefore cannot agree with Baetjer when she writes that "there appears to be no very convincing evidence that women are more susceptible to lead poisoning than men." The evidence that, given sufficiently large doses, women are more likely to develop lead poisoning than men, must be accepted, while the fact that under these circumstances they are more likely to abort or to lose their children in the first year of life is established beyond doubt, and the wisdom, therefore, of excluding women from the dangerous lead occupations is manifest.

It must be remembered, however, that conditions in the lead industries today are in most cases quite different from those which produced the alarming results reported in the pottery industry in the early years of this century, and where the quantity of lead in the atmosphere can be kept below $1 \mathrm{mg}$. per 10 cu. $m$. there is no evidence that women differ from men in the readiness with which they show symptoms of lead poisoning.

During the war opportunity occurred of watching for about three years the effect of lead work on 500 women, of whom one group of 150 were employed on an operation more hazardous than the rest, though still light. The lead content of the atmosphere was low $(0.75 \mathrm{mg}$. per $10 \mathrm{cu} . \mathrm{m}$.), while the lead in urine of men working side by side with these women varied between $0.075 \mathrm{mg}$. and $0.125 \mathrm{mg}$. per litre, with a mean of 0.9 . These women showed no greater incidence of menstrual abnormalities or of sickness absence than other non-lead workers. But freedom from other effects are not certain. Out of twenty pregnancies it was possible to follow the results of fifteen, and in three cases a stillbirth was reported. These women had all been removed from lead work as soon as pregnancy was disclosed. Though the incidence of miscarriage in this small group is seven times the normal, these numbers are far too small to have statistical significance, since such a finding might have happened by chance in as many as 11 per cent. of cases, but it is recorded in case other observers should have a similar opportunity and be able to add to the numbers.

Consideration of all the evidence, however, would suggest that it is unwise to employ women on operations which expose them to dust or fume in more than minimal quantities, and the soundness of the Factory Regulations in prohibiting women from employment in these operations is fully confirmed.

Age.-Children are regarded as more liable to lead poisoning than adults. It is very difficult to produce conclusive evidence on this point. Legge and Goadby (1912) state that surgeons to lead factories regard them as twice as susceptible as adults, but no figures are given to support this. Where cases of contaminated water supply have resulted in poisoning, it is stated that women and children are the first to succumb. There may, of course, well be other factors to account for this : for instance many men are away from home much more than their families and many, certainly, have a marked antipathy to water as a beverage.

Nye (1933) has recorded the disastrous effects on the kidney in young children who have been heavily exposed to lead in early childhood, and despite the paucity of sound statistical evidence the wisdom of excluding young people from lead exposure cannot be questioned.

Susceptibility.-Pre-employment medical examination is required in most lead trades. This is intended to exclude from this work those whom it is thought might be impaired by it. Those with hypertension, nephritis, peptic ulcer, or epilepsy are better not put to lead work, nor should be the slovenly worker of low intelligence. Where possible it is wise to choose the intelligent, clean, co-operative, well-groomed man of 25 for this work.

That people vary in their susceptibility to lead poisoning is generally recognized. This may be due to fundamental individual differences in metabolism or it may be due to less profound differences such as dietary habits, infections, and malnutrition (Hamilton, 1925 ; Minot, 1938 ; Tompsett, 1939). Unfortunately it is nearly always impossible to detect susceptibility before the individual starts work. There is however one pointer which is occasionally of use, the family history. Oliver (1916) reported well established cases of family susceptibility, and Legge and Goadby (1912) support this. They report the case of one family where three sons, two daughters, and the father all suffered from lead poisoning. I have 
reported one such case (Lane and Lewey, 1935) and have since seen a second example of this family susceptibility, in which two brothers who did not live together and in whom there was no apparent common factor, beyond the fact that they were brothers, suffered from lead intoxication following very minor degrees of exposure. It would seem that an inborn difference of susceptibility may be encountered.

\section{Supervision}

Clinical.-The clinical picture of plumbism is so well known that no attempt will be made to describe it here. Lead has been described as the second great imitator. While this is perhaps true, it must also be remembered that lead workers are not immune from the ills that the rest of mankind is heir to, and that care and sound clinical judgment are necessary in assessing any symptoms which are presented. In passing, it might be well to stress that the earliest symptoms of lead poisoning are often vague : the patient may be moody, irritable and unco-operative, his work may fall off in quantity and quality, and he may be unnaturally tired and yet unable to sleep. Those who are poisoned by lead tetra-ethyl have a symptom complex quite different from that of ordinary plumbism: here sleeplessness is particularly well marked and is accompanied or often preceded by bad and characteristic dreams; in these cases, too, symptoms are often associated with diarrhœa instead of the constipation usually associated with plumbism. The co-operation of intelligent foremen who know the signs of early trouble is often of great value in the detection of early symptoms in their men.

The supervision of lead workers will, however, have failed if the doctor awaits the onset of symptoms by which to judge the safety or otherwise of working conditions. Always he must have in mind that his work is preventive. He is supervising a group ; and, while he must be on the look-out for the individual who is specially susceptible, his observation of the group should be such that he will be able to keep working conditions at such a level of perfection that symptoms of lead poisoning do not occur, even among the susceptibles. To achieve this he will rely upon physical signs and upon laboratory aids.

Physical Signs.-The early physical signs of lead poisoning are not numerous, but minor departures from normal are not difficult to observe when the doctor is seeing those in his care each week or each month.

Pallor.-The pallor of lead intoxication is a definite and important sign and calls for action when present. It is an ashen hue and is often associated with a pinched expression about the nose and the sides of the forehead-these latter accompaniments serve in the difficult distinction between the pallor of lead intoxication and the paleness common among those who work in high temperatures, such as coal miners and cotton-room operatives. It has been suggested that this pallor is due to spasm of the capillaries of the skin of the face. Pallor, when present, is an important sign, but it is not always present in those suffering from lead intoxication.

Tremor.-A fine tremor is said to be seen frequently among lead workers and it is often accompanied by fibrillary twitching. - This condition may precede paralysis by some months, and is rarely seen in modern industry.

The Lead Line.-The lead line is an extremely useful sign, and in any inspection of lead workers it provides information of value. Known in Great Britain as the Burtonian line, it consists of a deposit of minute bluish grey particles in the substance of the gum and occurs typically about $1 \mathrm{~mm}$. from the tooth. There are various theories as to the mechanism of its production. All are agreed that the appearance is caused by particles of lead sulphide produced by the action of sulphuretted hydrogen on lead, and most observers agree that the sulphuretted hydrogen comes from the decomposition of protein food about the teeth, or from unhealthy gums; for this reason a blue line will not be found in a perfectly clean and healthy mouth. There is not the same unanimity about the route taken by the lead. The older French workers (Renon and Latron, 1900) thought it was secreted in the saliva. Other observers have attributed it to direct absorption by the mucosa of lead entering by the mouth, and there seems little doubt that a blue line can be caused in this way. Goadby (1910) in his report on the pottery industry, reports definite blue lines in workers at the end of one day's work in a dusty process, and in the examination of many hundreds the greater frequency of the blue line on the buccal side of front teeth would lend some weight to this view. The weight of evidence, however, supports Aub and others (1926) in the firm belief that the more usual mechanism is that lead is brought to the gingival margin by the circulation. The appearance of blue lines in cats who received their lead by injection supports this view. This is important, because if this is so the presence of a blue line is a significant finding and does indicate recent circulation of excess lead in the blood stream.

There are various practical points to be made in connexion with the blue line. In examining for it 
the use of a lens and a good light are essential ; an illuminated lens is the most convenient instrument to use. The fully developed blue line will rarely be seen nowadays in a good factory, but a few granules about one or two teeth is not uncommon ; these will not be detected without careful examination. A blue line is never seen in the edentulous.

Aub and others (1926) have drawn attention to changes in the gums before the appearance of a blue line-a precursory hyperæmia is certainly not uncommon.

There are various conditions from which a blue line must be distinguished ; the bluish discoloration of pyorrhœa ; this is diffuse and affects the gum up to the margin and should present no great difficulty (though it may accompany a true blue line and is then more difficult to distinguish). Equally common is the appearance presented by sub-gingival tartar which contains carbon, either from urban life or from previous occupation; on cursory examination it is impossible to distinguish this condition from a true blue line. The suggestion that the corner of a visiting card slipped between the gum and the tooth will assist is valuable in some cases, but not in the more difficult ones where there are only a few granules to be found, and where the blanching of the gum brought about by the insertion of the visiting card obscures the picture. By far the best and safest way is to remove any tartar from the particular tooth or teeth and to re-examine. The appearance of the bismuth line should cause no real difficulty, as its black colour distinguishes it from the true blue line of lead, nor should the brownish deposit of pigment in the gums found in some dark people present any cause for doubt. Another manifestation of lead absorption is described, namely massive staining of the buccal mucosa. This is comparatively rare nowadays and has no different significance from the ordinary blue line.

A blue line is evidence of absorption and circulation of lead in quantities in excess of normal, but its development depends on a second factor, sulphuretted hydrogen, which in turn depends on the presence of natural teeth and on indifferent dental hygiene. Despite this, experience has shown that while a blue line is certainly not to be regarded as a sign of poisoning in the individual, its frequency in a known group is of considerable value in assessing the hazard to which that group is exposed. Table 3 shows, in two groups of workmen, the result of reducing lead absorption, principally by reducing hours of work from 50 to 42 hours per week. The lead content of the air remained unchanged $(1.5 \mathrm{mg}$. per $10 \mathrm{cu}$. m.).

It is evident from these figures that here the blue line was a sensitive index of the level of lead absorption of the group. It must be stressed once again that this was not a gross blue line, but a very small gingival deposit of lead sulphide which usually clears from the gums in a few weeks if all absorption ceases. The heavy well developed blue line which is easily seen by the naked eye may take as much as twelve months to clear after all lead exposure has ceased ; this type of blue line is now rarely seen in industry, and when present it suggests heavy absorption (Goadby, 1910).

In dealing with the individual workman the blue line tells us no more than is already known, that he is a lead worker and has more circulating lead than normal. It is not a sign in the individual of poisoning. But the incidence of blue lines in a group is a useful finding.

The value to be placed on the blue line is stressed

TABLE 3

BLUE LINE EFFECT

\begin{tabular}{|c|c|c|c|c|c|c|}
\hline \multirow[t]{2}{*}{ Group } & \multirow[t]{2}{*}{ Year } & \multirow{2}{*}{ 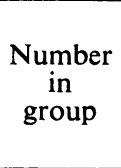 } & \multicolumn{2}{|c|}{$\begin{array}{l}\text { Cases } \\
\text { of blue } \\
\text { line }\end{array}$} & \multirow{2}{*}{$\begin{array}{c}\text { Punctate } \\
\text { count } \\
\text { (average } \\
\text { in } \\
1,000 \text { 's) }\end{array}$} & \multirow{2}{*}{$\begin{array}{l}\text { No. of } \\
\text { men } \\
\text { free }\end{array}$} \\
\hline & & & No. & $\%$ & & \\
\hline \multirow[t]{2}{*}{1} & 1943 & 66 & 18 & 27 & $1 \cdot 8$ & 9 \\
\hline & 1946 & $61^{*}$ & 5 & 8 & 0.5 & 4 \\
\hline \multirow[t]{2}{*}{2} & 1943 & 123 & 43 & 35 & $2 \cdot 5$ & 11 \\
\hline & 1946 & $98 \dagger$ & 16 & 16 & 0.6 & 6 \\
\hline
\end{tabular}

* Five men left before 1946 ; none of them had a blue line in 1943. + Twenty-five men left before 1946; four of them had a blue line in 1943 .

because it is a simple clinical observation which can be made by any doctor who takes the trouble to become familiar with the technique and who provides himself with a simple illuminated lens. He will frequently, however, require to remove tartar before making a decision as to whether a "blue line" is genuine.

\section{Laboratory Methods}

Useful as a clinical examination is, it cannot be regarded as an entirely satisfactory means of supervision of lead workers. The search for other efficient objective methods has been persistent. The most important of these depend upon the measurement of : (1) lead excretion, (2) lead levels in the circulating blood, and (3) blood changes.

The Medical Inspector of Factories (1945) has recently drawn attention to the use of " figures" in the diagnosis of lead poisoning, and has rightly stressed the importance of their proper use. While 
great help is to be obtained from such investigations in the right circumstances, their interpretation demands experience and a knowledge of the physiology and pathology of lead absorption and excretion. Furthermore the accuracy of the figures in question must be beyond doubt. The improvements in modern chemical methods are such that the accurate determination of very small quantities of lead in biological materials is now possible, but the very delicacy of the methods renders it specially important that the greatest care is taken in the collection of the sample, while the laboratory in which the work is done must be suitable. To attempt, for instance, to carry out estimations of this type in the ordinary laboratory of a factory using lead would be almost certain to give trouble. Furthermore, experiment has shown that reliable results are likely to be obtained only when the chemist himself has considerable familiarity with the methods and their difficulties. Odd samples analysed from time to time in a routine hospital laboratory are not likely to be of value. The method used in the determinations discussed below is a standard dithizone method as described by Kench (1940).

\section{Normal Absorption and Excretion of Lead}

The daily intake of lead among the general population has been the subject of much research, and the literature has been reviewed by Pope (1932) and by Monier-Williams (1938). The chief source is to be found in the food and in the drinking water, and the average quantity inhaled as dust has been estimated as $0.08 \mathrm{mg}$. daily (Final Report of the Departmental Committee on Ethyl Petrol, 1930), making an average total normal intake of about $0.50 \mathrm{mg}$. daily. This figure compares well with that arrived at by Kehoe and others (1935).

This lead is excreted partly in the fæces and partly in the urine. Work by Aub and others (1926) suggests that the quantity excreted by the gut is about 2.5 times greater than that excreted by the kidney, even when lead has been given subcutaneously, but more recent work by Kehoe and others
(1943) suggests that renal excretion equals or exceeds that by the alimentary tract. The presence of lead in normal urine has been amply demonstrated by numerous workers, and the importance of considering this normal level before using urinary lead excretion as an indication of lead exposure is apparent.

The normal levels of excretion in urine and fæces are presented in Table 4 . When intake is increased the lead content of fæces and urine rises and storage of lead takes place.

In industrial exposure the level of urinary lead does not continue to rise, but reaches a level which is characteristic of the exposure. When such exposure ceases, urinary excretion will gradually drop over the ensuing months.

The value of "lead in urine" determinations in industry is therefore to give a measure of exposure. This method must be applied to the group, and the only satisfactory standard is to apply a range of values with a mean. Kehoe and others (1943) set this mean at $0.1 \mathrm{mg}$. per litre, with samples not infrequently reaching $0 \cdot 150$ and rarely $0 \cdot 20$. This is a severe standard, and in my experience safety can be achieved at a slightly higher level; a mean of 0.125 with occasional figures of 0.20 and, rarely, figures of $\mathbf{0} \cdot 23$. Large groups of men subjected to this degree of exposure and with no toxic symptoms have been observed for over ten years; though it seems obvious that the lower the figure can be maintained the better.

When absorption exceeds a certain level in the group, cases of plumbism are likely to occur, but not necessarily in those individuals with the higher lead concentrations. There is no exact correlation between the concentration of lead in the urine and clinical plumbism, though on an average those with a high urinary excretion are more likely to succumb.

Not infrequently healthy men have concentrations of lead in their urine of $0.25 \mathrm{mg}$. per litre or even more, whereas cases showing signs of clinical plumbism may have " lead in urine" concentrations within normal limits. Nevertheless, confirmed

TABLE 4

NORMAL LEAD EXCRETION : FINDINGS OF VARIOUS AUTHORITIES

\begin{tabular}{|c|c|c|c|c|c|c|}
\hline \multirow[b]{2}{*}{ Urine } & \multicolumn{5}{|c|}{ Authority } & Quantities \\
\hline & $\begin{array}{l}\text { Ethyl Petrol Departmental C } \\
\text { Tompsett (1939) } \\
\text { Badham and Taylor (1927) } \\
\text { Kehoe and others (1935) }\end{array}$ & $\begin{array}{l}\text { om } \\
\cdots \\
\cdots \\
\cdots\end{array}$ & $\begin{array}{l}\text { tee } \\
\cdots \\
\cdots \\
\cdots\end{array}$ & $\begin{array}{l}\cdots \\
\cdots \\
\cdots\end{array}$ & $\begin{array}{l}\cdots \\
\cdots \\
\cdots\end{array}$ & $\begin{array}{l}0-0.108 \mathrm{mg} . \text { per litre } \\
0.04-0.05 \mathrm{mg} \text {. in } 24 \text { hours } \\
0.03-0.15 \mathrm{mg} \text {. in } 24 \text { hours } \\
0.05-0.1 \mathrm{mg} \text {. in } 24 \text { hours } \\
0.02-0.08 \mathrm{mg} \text {. per litre }\end{array}$ \\
\hline Fæces & $\begin{array}{l}\text { Tompsett and Anderson (193 } \\
\text { Kehoe and others (1935) }\end{array}$ & 5) & $\begin{array}{l}\cdots \\
\cdots\end{array}$ & $\begin{array}{l}\cdots \\
\cdots\end{array}$ & $\begin{array}{l}\cdots \\
\cdots\end{array}$ & $\begin{array}{l}0.20-0.4 \mathrm{mg} \text {. in } 24 \text { hours } \\
0.02-0.39 \mathrm{mg} \text {. in } 24 \text { hours }\end{array}$ \\
\hline
\end{tabular}


repeated high lead concentrations in urine $(0 \cdot 25 \mathrm{mg}$. per litre) should call for action in the individual case.

Sampling.-While a twenty-four-hour sample may be desirable, it is impracticable as a general routine in industry, and as a result considerable investigation of the validity of spot sampling has been carried out in America by Levine and Fahy (1945). These workers have shown a high correlation between specific gravity and lead concentration in over 1,150 samples. They recommend that spot sampling be expressed as milligrammes per litre adjusted to a specific gravity of 1024 ; it is usually found in this country that results using their correction tend to be high. There is, however, every justification for using this spot sampling method, though more work upon it in Great Britain is desirable. The actual collecting of samples requires care and a room specially set aside for the purpose, but elaborate bathing as required by Kehoe has not been found necessary in practice.

Estimation of lead in fæces is not a reliable measure of absorption and is not the type of investigation which lends itself to use in industry. Much of the lead in the frecs of a lead worker has never been absorbed, but has passed through the gut without affecting the systemic lead level. Where carried out on a group of men, however, such estimation will give an indication of the exposure to which that group is subjected.

Lead in Blood.-The estimation of lead in blood has been carried out in recent years on a wide scale. The same mistake has been made in interpreting these results as has been made with other laboratory investigation : too much has been claimed for the method, and workers have attempted to establish critical values above which they claim poisoning occurs, and below which safety may be presumed. Wide experience shows that there is no justification for such claims (Sawyer and others, 1939). Personal observations have disclosed healthy lead workers showing values as high as $0.16 \mathrm{mg}$. per $100 \mathrm{ml}$., while a case of plumbism showed persistent values within the normal range $(0.08 \mathrm{mg}$. per $100 \mathrm{ml}$.). That the blood lead values of groups of lead workers are greater than normal has been shown by Dreesen (1941), but changes in lead absorption are not so quickly reflected in these figures as they are in the "lead in urine" figures (Kehoe, 1935). Routine venupunctures among factory workers are not likely to be regarded with favour, and since other more effective methods for control are available "lead in blood" estimations are not regarded as suitable for routine use in industry.

Blood Changes.-The changes in the blood produced by lead are definite, but are not entirely specific. Anæmia is found after heavy exposure and is hypochromic in type. The number of red cells falls, and this is accompanied by a corresponding or slightly greater fall in the hæmoglobin. The decrease in the number of red cells is claimed by Aub and others (1926) to be due to their more easy destruction as a result of the physical changes which take place in the red cell envelope as a result of the presence of lead. The anæmia differs from ordinary hæmolytic anæmia (Rimington, 1938) and is associated with the appearance of coproporphyrin III in the urine. Work by Manchester investigators, however (Kench, Gillam, and Lane, 1942), showed the diminution of hæmoglobin in lead intoxication to result from restricted formation of protoporphyrin rather than from its non-utilization, as had been suggested by Rimington. More recently McFadzean

TABLE 5

PUNCTATE BASOPHIL DANGER LEVELS : FINDINGS OF VARIOUS AUTHORITIES

\begin{tabular}{|c|c|c|c|}
\hline Autho: & & & Per million \\
\hline $\begin{array}{l}\text { Schmidt (1919) } \\
\text { Lehmann (1919) } \\
\text { Trautmann (1924) } \\
\text { Naegeli (1919) } \\
\text { Sellers (1925) } \\
\text { Belknap (1940) } \\
\text { Johnson (1937) } \\
\text { Lane (1931) . . }\end{array}$ & $\begin{array}{l}\ldots \\
\ldots \\
\cdots \\
\cdots \\
\cdots \\
\cdots \\
\cdots\end{array}$ & $\begin{array}{l}\ldots \\
\ldots \\
\ldots \\
\ldots \\
\ldots \\
\ldots\end{array}$ & $\begin{array}{r}100 \\
200 \\
300 \\
500 \\
1,000 \\
1,000 \\
2,000 \\
3,000\end{array}$ \\
\hline
\end{tabular}

and Davis (1949) had advanced an hypothesis reconciling the theories of faulty hæmoglobin synthesis and hæmolysis.

Estimations of hæmoglobin are of considerable value in the supervision of lead workers; though it is unusual nowadays to find marked anæmia in a lead worker, a persistent hæmoglobin below 85 per cent. in a man should call for investigation.

Changes have been reported in the white cell ratio (Ferguson and Ferguson, 1934 ; Shiels, 1936), but these are not sufficiently constant to be of practical value.

Punctate Basophilia.-The most important change for the purpose of control is that of punctate basophilia. This has been the subject of numerous investigations by a variety of workers. Their results are so contradictory that the literature of the subject is in a state of chaos (Table 5). Most of the disagreement results from workers asking too much of this method and from their attributing to it an undeserved specificity and accuracy. It must be understood at the outset that vastly different results will be obtained if different methods are used to estimate the degree of punctate basophilia, for 
example, different staining methods and different methods of microscopy.

Furthermore, different results will be found among different types of lead workers, according to the nature of their exposure. The following is a brief summary of the uses and abuses of this method of control and its practical value to the clinician.

Punctate basophilia appears in a number of conditions, notably pernicious anæmia, the leukæmias, and cachexia following neoplasm. In none

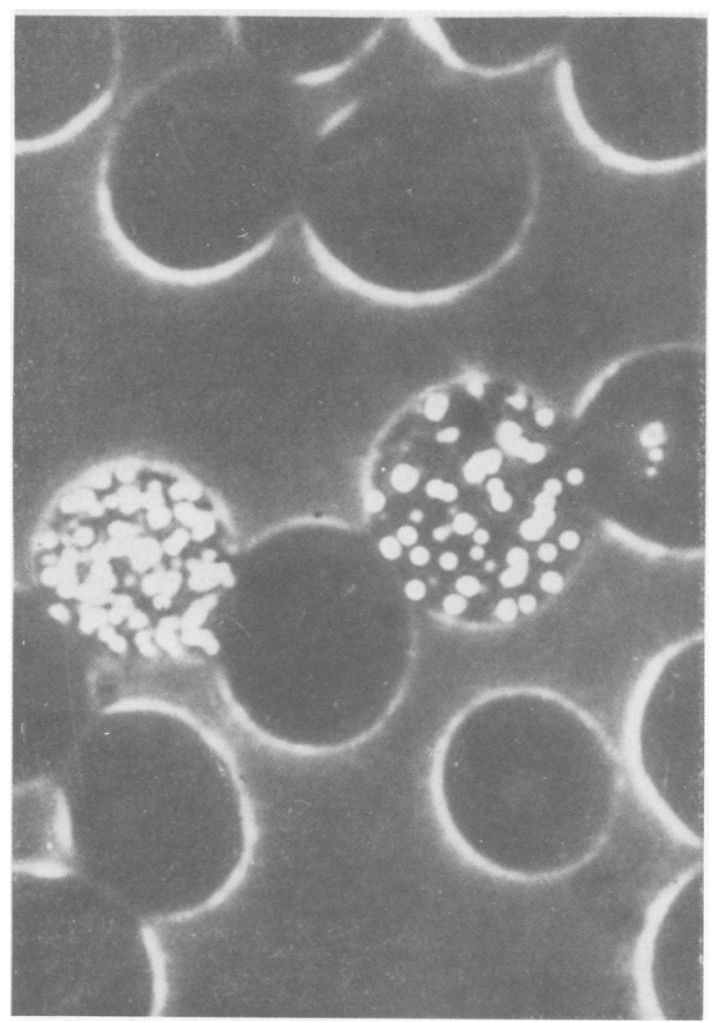

FIG. 10.-Erythrocytes showing punctate basophilia as seen by dark-ground illumination.

of them, however, is it so frequently observed or in such a marked degree as in lead poisoning; this association was first recorded by Behrend (1899). The work of Key (1924) did much to establish the present conception of the stippled cell as a young cell, and the stippling as a granular degeneration of the basophilic substance of the cytoplasm. The close association of punctate basophilia with polychromasia and with reticulation is now generally accepted (Whitby and Britton, 1933).

Certain workers have abandoned the use of punctate basophilia in the supervision of lead workers, and have fallen back on reticulocyte counts (Fleckel and Tschernow, 1930), while one of the most widely used methods, the basophilic aggregation test (McCord and others, 1924), depends on the vital staining of hæmolysed red cells. While these methods are obviously open to objection and are not as specific as punctate basophil counts, they have their uses and possess the advantage that staining methods are laid down and must be carried out, and the resulting microscopical examination is not difficult; so that the variation in the results of different workers is less extreme.

There is little doubt, however, that stippled cell counts are more specific and have definite value, provided always they are carried out in a uniform manner and the results are interpreted with care and reserve.

Method.-A thin film is prepared on a suitably thin glass slide. Fixation is by methyl alcohol followed by staining with an alkaline methylene blue (methylene blue 2 parts, sodium bicarbonate 12 parts, distilled water 400 parts). Washing with tap water is continued until the film has a sea-green colour.

Much trouble has arisen because the fine stippling demonstrated by this method of staining is often difficult to see when using transmitted light, and after short spells the work becomes tedious and the fatigue it induces is likely to lead to many stippled cells being missed. For this reason dark-ground illumination should be used for this work. When employing this method the red cells are seen as circles of light and the stippling appears as golden dots within the circle (fig. 10). Using a $1 / 12$ oil immersion objective, a hundred fields are counted. Ten contiguous fields are scrutinized in 10 different parts of the slide. The size of the granules is noted. An estimate of the number of red cells examined is made by means of an Fhrlich stop, and the number of punctate cells per million erythrocytes is calculated.

This method achieves the ease of counting of the basophilic aggregation test, while retaining the somewhat greater specificity of the stippled count. Counts are considerably higher than when transmitted light is used (approximately twice as great ; fig. 11).

Use of Results.-In 1931 I (Lane, 1931) showed that minor degrees of punctate basophilia were to be found in normal individuals, and though later work and a larger series of cases would lead me now to suggest that the incidence of punctate basophilia in the normal population is less than was reported at that time, there can be no doubt that this exists. Punctate basophilia varying between one and three thousand per million has been observed in 8 per cent. of normal individuals when films have been examined by this technique. Kehoe (1935) has 
reported counts of over 1,000 per million in 6 per cent. of a group of over 700 normal people. To place great reliance, therefore, on single punctate counts is unsound.

In order that punctate counts may be of value in supervising the lead worker they must be repeated

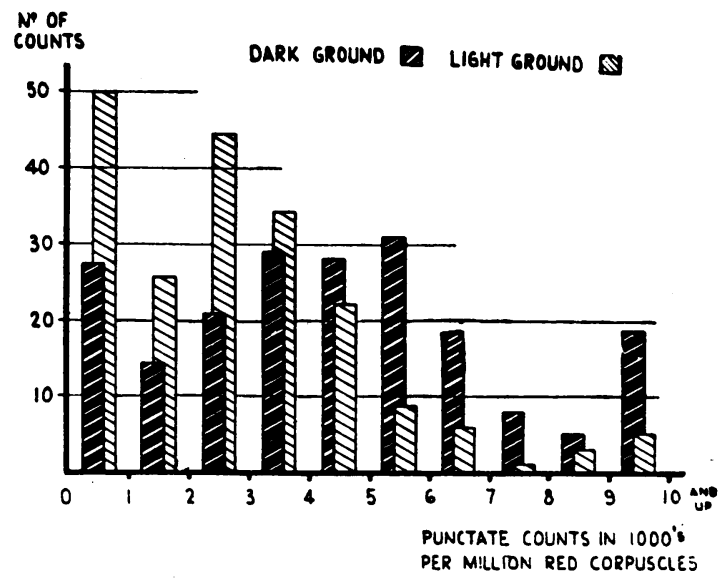

FIG. 11.-Punctate counting, dark- $v$. light-ground methods : two hundred samples.

at frequent intervals, and departures from the normal and general trends must be noted. It has been reported previously (Lane, 1931) that greater significance should be placed on the presence of large granules, and a sharp rise in the count accompanied by the appearance of coarse stippling usually indicates recent increased absorption. Occasionally, where lead absorption has persisted at a fairly high level, the punctate count may drop to a low or normal level despite the continued absorption of lead in undesirable quantities. This change is usually accompanied by a drop in the hæmoglobin level. For this reason a routine hæmoglobin estimation should be made at the same time as the blood is taken for the punctate count. The Haldane method of determination has been found satisfactory in practice.

Punctate basophilia $(1-5,000)$ estimated by the method described above, is likely to be present in minor degrees of lead absorption and in the complete absence of signs or symptoms of poisoning, and appears to be consistent with good health. A number of workers with these small counts have been kept under observation for twenty years, and no departure from normal has been detected (figs. 7 and 8). This supports the finding of Belknap (1940).

The Group.-While a normal unexposed group may show minor degrees of punctate basophilia, $\mathbf{B}^{*}$ this is confined to less than 10 per cent., the majority of the group being free. Lead exposure of significant degree manifests itself by the appearance of punctate basophilia of varying degrees in most members of the group ; most counts show a rise and the mean is raised. The extent of the basophilia and the actual counts will depend on the degree and nature of the lead exposure. It is sometimes suggested, for instance, that exposure to lead fume does not give rise to punctate basophilia ; this is by no means always true. Extensive punctate basophilia in a group of men exposed to nothing but lead fume has been observed on several occasions. Often, however, this type of work does not involve the same degree of dosage with lead as does dusty lead work, and it is probably for this reason that the changes are often less marked (fig. 12).

In those exposed to lead tetra-ethyl punctate basophil count have not the value they have with other lead compounds.

In summary it may be stated that this method provides an easily performed objective measure of absorption for the group, and may single out the individual who is absorbing larger doses of lead than his fellows. This is the value of this particular investigation; too much must not be asked of it,

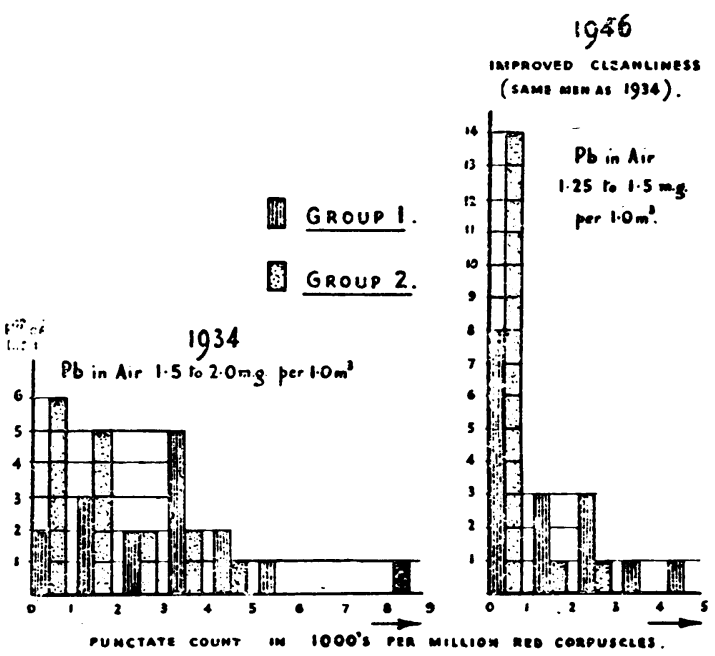

Fig. 12.-Use of stippled count : two groups of sixteen men on different processes in the same shop.

but it should have a place in any routine control of groups of workers exposed to inorganic lead compounds.

In making a diagnosis of lead poisoning, the finding of punctate basophilia is of value. It is almost invariably present if the patient is seen within a short time of lead exposure. Cases of 
lead poisoning have very rarely been seen without marked punctate basophilia, but (excepting cases of tetra-ethyl lead poisoning) these have always been associated with a low hæmoglobin ( 60 per cent.), and it would seem that here the absence of stippled cells is the result of a severe depression of the bone marrow, resulting in the production of a small number of young red cells. On the other hand a high punctate count may be encountered without any lead poisoning, and occasionally even in a person engaged on- work involving a comparatively low lead hazard.

Siderocyte Count.-Case (1945) has studied the effect of lead absorption on the siderocytes of the blood. These erythrocytes contain fragments of non-hæmatin iron which is stainable by appropriate methods, and in his view they are of value in estimating lead absorption. Further investigation of this method of routine control of lead workers is awaited.

The estimation of lead in urine and of punctate basophilia are the laboratory methods of choice in the supervision of the lead worker. Each has a wide range of values, and moderately high figures in some individuals are consistent with continued good health. The inexperienced clinician must therefore resist the temptation to make a diagnosis of plumbism merely on the results of these tests ; such a diagnosis can only be made on a careful consideration of the whole history and clinical picture, together with the help these tests give. On the other hand, when applied to the group, a small general shift towards the higher values is of significance and will call for detailed investigation of the conditions of work.

Treatment.-Should a worker show evidence of abnormal absorption (pallor, vague symptoms, drop in hæmoglobin, continued shift in punctate count) he must receive treatment. This merely means stopping lead absorption by suspending him from lead work. Such suspension should not involve financial hardship, and should last for about three months. Any question of return to the old work must receive careful consideration. If it has been possible to modify the operation or conditions of work-including hours-which were responsible for the trouble, the man may be allowed to return. If no such modification is possible he should be considered unsuitable for that particular hazard.

Workmen should not be allowed to go back to a heavy hazard immediately on their return to work after a heavy infection; there is ample evidence that infection is likely to precipitate lead mobilization.
The treatment of acute toxic episodes is sufficiently well known to require no comment.

Prophylaxis. - In the past emphasis has been laid on regular saline cathartics, on vitamins, and on citrates as routine treatment for the lead worker. I should like to express strong disapproval of any such measures. There is one way to prevent lead poisoning and one way only, and that is to make the process safe, and experience has shown that this can be done in the most unpromising trades. Anything which is likely to divert attention from this objective is unwelcome. Furthermore. there is no convincing evidence that these other methods of treatment have any real value in the prevention of poisoning. Milk has long been regarded as a useful preventive measure; Legge and Goadby (1912) thought it acted by reducing the acidity of the stomach. Aub (1926) disagreed with this view, but supported its use on account of its calcium content. More recently Tompsett (1939) has added further experimental evidence to the contention that milk interferes with the absorption of lead in the gastro-intestinal tract.

While most lead is probably absorbed by the respiratory tract, there is little doubt that a certain amount may gain entrace to the body by way of the gastro-intestinal tract. In dusty lead trades, therefore, where lead dust may adhere to the upper respiratory tract and finally find its way to the gut, there may be some scientific basis for giving milk before work; but most of these trades nowadays are capable of adequate engineering control, and this must be regarded as the method of choice. When complete control is not possible, milk may be given. It must be emphasized that there is no need to give milk to the majority of lead workers. This is important now milk is short, and claims for it should be resisted as being against the best interests of the community. There is no doubt that much milk is being diverted from more useful purposes to lead workers exposed to a small hazard who have no real need for it. Conditions are better than in the old days, wages are good, and rationing ensures adequate supplies of essential foods. These are important factors in the care of the lead worker, and extra milk is no longer justified for the majority.

The importance of education of the worker himself must be stressed. He must understand fully the dangers of his work. No attempt must be made to hide it or to minimize it, but he must at the same time be shown his own responsibilities in any safety programme. This needs patience and hard work on the part of the doctor. He must inspire employers and workers alike with enthusiasm for safe working conditions. The employer can, 
and must, do a great deal, but final and complete success will be impossible without the co-operation of the workman. This co-operation is forthcoming if the approach is the right one : the responsibility for procuring it lies with the doctor.

\section{Conclusion}

In these lectures controversial subjects have been dealt with, and an attempt has been made to show how the supervision of the lead worker may be carried out. That these methods can be successful is illustrated in fig. 5, which shows the incidence of lead poisoning over the last twenty-five years in a large electric accumulator factory in which these measures have been adopted.

I wish to acknowledge the help and encouragement accorded to me over some twenty years by the Directors and Employees of the Chloride Electrical Storage Company Limited. I also wish to acknowledge the help of Mr. H. Varley for lead-in-urine determinations, and of Mr. R. Gray for preparing diagrams.

\section{REFERENCES}

Annual Report of the Chief Inspector of Factories. Cmd. 4931. (1944). H.M.S.O. London.

Annual Report of the Chief Inspector of Factories. Cmd. 6992 (1945). H.M.S.O. London.

Aub, J. C., Fairhall, L. T., Minot, A. S., and Reznikoff, P. (1926). "Lead Poisoning." Medical Monographs. Vol. 7. Williams and Wilkins, Baltimore.

Badham, C., and Taylor, H. B. (1927). Report of the Director General of Public Health, New South Wales, for year 1925. Sydney.

Baetjer, A. M. (1946). "Women in Industry." Saunders, Philadelphia.

Behrend, F. (1899). Suppt. Dtsch. med. Wschr., 25, 254.

Belknap, E. L. (1936). J. industr. Hy8., 18, 380.

(1940). Industr. Med., 9, 505

Bell, W. B., Williams, W. R., and Cunningham, L. (1925). Lancet, 2, 793.

Cantarow, A., and Trumper, M. (1944). " "Lead Poisoning." Williams and Wilkins, Baltimore.

Case, R. A. M. (1945). J. Path. Bact., 57, 271.

Dreesen. W. C., and others (1941). U.S. Publ. Hlth. Bull., 262. Washington, D.C.

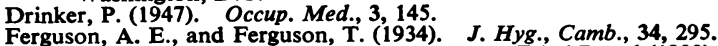

Final Report of the Departmental Committee on Ethyl Petrol (1930). H.M.S.O. London.

Fishberg, A. M. (1939). “ Hypertension and Nephritis.” p. 609. Baillière, Tindall, and Cox. London.

Fleckel, I. M., and Tschernow, I. G. (1930). Z.bl. Gewerbehyg., 7, 65.

Flury, F. (1934). "Blei in Handbuch der experimentellen Pharmakologie." Hefter, A., and Heubner, W. Vol. 3., pt. 3, kologie." Hefter, A., and

Goadby H K (1910). " Report of Departmental Committee on Manufacture of Earthenware and China" (see below).

Hamlin, L. E., and Weber, H. J. (1947). J. Industr. Hyg., $29,367$.
Hamilton, A. (1925), “Industrial Poisons in the United States" Macmillan and Co. New York.

Hepple, R. A. (1930). Final Report of the Departmental Committee on Ethyl Petrol. H.M.S.O. London.

Johnson, T. A. (1937). Penna. Med. J., 40, 741.

Kehoe, R. A., Thamann, F., and Cholak, J. (1935). J. Amer. med. Ass., 104, 90.

(1935). J. Med. Cincinnati, 16, 527.

-and others (1943). J. of industr. Hyg., 25, 71.

Kench, J. E. (1940). Biochem. J., 34, 1245.

Key Gillam, A. E., and Lane, R. E. (1942). Ibid., 36, 384.

Key, J. A. (1924), Amer. J. Physiol., 70, 86.

Lane, R. E. (1931). J. industr. Hyg., 13, 276

- (1936). Lancet, 2, 206.

Legge, T. M. (1934). "Industrial Maladies." Oxford University Press. London.

-and Goadby, , K. W. (1912). "Lead Poisoning and Lead Absorption." London.

Lehmann, K. B. (1919). "Lehrbuch der Arbeits und Gewerbe-

hygiene," Leipzig. (1945) J. industr. Hyg., 27, 217

McCord, C. P., Minster, D. K., and Rehm, M. (1924). J. Amer. med. Ass., 24, 1795

McFadzean, A. J. S., and Davis, L. J. (1949). Quart. J. Med. 18,69 .

Maclaren, J. P. (1927). “ Modern Methods of Medical Insurance Examination." Baillière, Tindall, and Cox. London.

Mayers, M. R. (1947). Occup. Med., 3, 77.

Minot, A. S. (1938). Physiol. Rev., 18, 554.

Monier-Williams, G. W. (1938). "Reports on Public Health and Medical Subjects," Ministry of Health. No. 88. London.

Naegeli, O. (1919). Folia Haematol., 24, 86.

Nye, L. J. J. (1933). "Chronic Nephritis and Lead Poisoning." Angus and Robertson. Sydney.

Oliver, T. (1914). "Lead Poisoning." p. 98. H. K. Lewis.

London." (1916).

Percival, T. (1774). "Observations and Experiments on the Poison

of Lead," London.
Platt, R. (1948). Ouart. J. Med., N.S., 17, 83.

Platt, R. (1948). Quart. J. Med., N.S.
Pope, T. H. (1932). Analyst, 57, 775.

Renon, L., and Latron, L. (1900). Bull. Mém. Soc. méd. Hôp. Paris.

$17,800$.
" Report of the Departmental Committee Appointed to Enquire into the Dangers Attendant on the Use of Lead and the Danger or Injury to Health Arising from Dust and other Causes in the Manufacture of Earthenware and China, and in the Processes Incidental thereto, including the Making of Lithographic Transfers." (1910). H.M.S.O. London.

Rimington, C. (1938). C. R. Lab. Carlsberg., 22, 454.

Russell A E. Jones, R. R. Bloomfield, J, J., Britten, R. H., and Thompson, L. R. (1933). "Lead Poisoning in a Storage Battery Plant.; U.S. Publ. Hlth. Bull., No. 205

Sawyer, R. A., Wagoner, R. W., and Erickson, A. A. (1939). Science 90, 11 .

Schmidt, P. (1919). " "Schrift a.d. Gesamtgebeit d. Gewerbehyg," pp. 42-64.

Sellers, A. (1921). J. ind. Hyg., 2, 361.

Shiels, D. O. (1936). Med. J. Aust., 1, 847.

Sigerist, H. E. (1943). In Introduction to " The History of Miners' Diseases" By G. Rosen Schuman. New York.

Symonds, B. (1923). J. Amer. med. Ass., 80, 232.

Tanquerel des Planches, L. (1839). "Traité des Maladies de Plomb, ou Saturnines." 'Paris.

Teleky, L. (1937). J. industr., Hyg., 19, 1.

Tompsett, S. L. (1939). Biochem. J., 33, 1237.

and Änderson, A. B. (1935). Biochem. J. 29, 1851.

Trautmann, A. (1924). Arch.f. Hyg., 94, 298.

U.S. Public Health Bulletin (1940), No. 259. Washington, D.C.

Whitby, L. E. H. ,and Britton, C. J. C. (1933). Lancet, 1, 1173. 